\title{
LEVEL OF ENVIRONMENTAL EDUCATION IN STUDENTS FROM POLAND, UKRAINE, SLOVAKIA AND THE CZECH REPUBLIC
}

\section{POZIOM EDUKACJI ŚRODOWISKOWEJ WŚRÓD STUDENTÓW Z POLSKI, UKRAINY, SŁOWACJI I CZECH}

\author{
Karolina Cynk $\mathbf{k}^{1(\mathrm{~A}, \mathrm{~B}, \mathrm{C}, \mathrm{D}, \mathrm{E}, \mathrm{F}, \mathrm{G})}$
}

${ }^{1}$ Uniwersytet Rzeszowski

Cynk K. (2017), Level of environmental education in students from Poland, Ukraine, Slovakia and Czech Republic. Rozprawy Społeczne, 3(11), s. 44-54.

Wkład autorów:

A. Zaplanowanie badań

B. Zebranie danych

C. Dane - analiza i statystyki

D. Interpretacja danych

E. Przygotowanie artykułu

F. Wyszukiwanie i analiza

literatury

G. Zebranie funduszy
Tabele: 8

Ryciny: 0

Literatura: 10

Otrzymano: 09.02.2017

Zaakceptowano: 19.04.2017

\begin{abstract}
Summary
Introduction. This article consists of two parts: the theoretical one, introducing several key terms, and the empirical part, presenting the analysis of sociological research. Explaining the concept of 'education' in the first part of the article allowed for formulating relevant hypotheses on students' approach to the problems of environmental protection.

Materials and methods. The proposed hypotheses were then verified with regard to the project executed in 2015, which investigated the position and role of environmental values in the value system of students from selected countries of Central Eastern Europe. The description of this research is presented in the second part of the article.

Results. The conclusions from the analysis with regard to the country and faculty of studies are rather disturbing. The findings revealed that the level of environmental education in students is relatively low. The overall comparative analysis demonstrated that students from the Czech Republic represented the highest level of environmental awareness compared to those from Ukraine, Poland and Slovakia. Further, the analysis took into consideration the students' faculty and showed that those studying natural sciences were only slightly better educated in environmental protection compared to students of humanities. This may indicate that even when young people receive environmental education, it does not help in creating a bond between them and the natural environment.
\end{abstract}

Conclusion. Although the findings should be treated with some caution, they still deserve serious consideration, and should stimulate further research in this area.

Keywords: environmental education, environmental protection, ecology, sociological research

\section{Streszczenie}

Wstęp. Artykuł składa się z dwóch części: teoretycznej - zawierającej konceptualizację kluczowych terminów oraz części empirycznej zawierającej analizę badań socjologicznych. We wprowadzeniu zdefiniowany został termin edukacja, co umożliwiło sformułowanie hipotez badawczych dotyczących stosunku studentów do problemów ochrony środowiska.

Materiał i metody. Zaproponowane hipotezy zostały zweryfikowane na podstawie danych zebranych podczas badań w 2015 roku, dotyczących miejsca i roli wartości środowiskowych wśród innych wartości akceptowanych przez studentów z krajów środkowo-wschodniej Europy. Opis tych badań został przedstawiony w drugiej części artykułu.

Wyniki. Wnioski z analizy, w której uwzględniono dwie zmienne: kraj studiów i kierunek studiów, są niepokojące. Wyniki wskazują, że poziom edukacji środowiskowej wśród studentów jest dość niski. Najwyższy poziom wyedukowania środowiskowego wykazali studenci czescy. Z kolei uwzględniając kierunek studiów można stwierdzić, że studenci nauk przyrodniczych byli nieco lepiej wykształceni w zakresie ochrony środowiska niż studenci humanistyki. Oznacza to, że nawet jeśli młodzi ludzie kształcą się w zakresie ochrony środowiska, nie przekłada się to na odczuwanie przez nich więzi z przyrodą.

Wnioski. Wyniki badań należy traktować z pewną ostrożnością, konieczne jest podejmowanie dalszych analiz w tym zakresie.

Słowa kluczowe: edukacja środowiskowa, ochrona środowiska, ekologia, badania socjologiczne

\footnotetext{
Adres korespondencyjny: Karolina Cynk, Uniwersytet Rzeszowski , ul. T. Rejtana 16c, 35-959 Rzeszów, e-mail: rss@ur.edu.pl, tel. 1787213 30 Copyright by: Copyright by: Państwowa Szkoła Wyższa im. Papieża Jana Pawła II w Białej Podlaskiej, Karolina Cynk warunkach 4.0 Międzynarodowe (CC BY-NC-SA 4.0, http://creativecommons.org/licenses/by-nc-sa/4.0/).
} 


\section{Introduction}

Throughout its history, humankind has consistently developed material culture, especially technology, but has developed spiritual culture relatively poorly, where hardly any progress has been made. The consequence of this is that people have not always made the best use of the products of their intellect. With respect to the natural world, people lacking this balance have tried to rule nature, and as a result have caused considerable damage to the natural environment for which they proved to have no effective remedy (Dobrzańska, Dobrzański, Kiełczewski 2008).

It was only relatively recently that people began to perceive nature as a complex system of which man is merely one part. Thus, people have changed their approach to the natural environment, and this further required changes in their centuries-old system of values. This new approach has created the need for a continuous and consistent process of educating people in environmental protection. The purpose of this is to change the way of thinking and attitudes of members of society, and also to make them aware of these problems so they start taking care of nature, prevent its destruction, and restore the balance in its functioning. These actions should be driven not only by the prospect of improving the quality of human life, but also the inherent value and beauty of nature alone.

\section{The core of environmental education}

To explain the terms environmental education we have to first explain the term education. First of all, education (Lat. educatio) is the action or process of teaching someone to develop their awareness. A more detailed understanding of the process of educating requires an explanation of the terms that are its components and which, as with the concept of education, still have no commonly accepted definition. The process of teaching, which is planned and systematic and involves sharing knowledge and skills through explanation in line with specific objectives, requires two participants - the teacher and the learner (Wolarski 2002). On the other hand, personal development is a psychological and pedagogical process influencing someone's personality and its formation. Personal development through education should instil habits and attitudes enabling people to find their own place in society. Teaching, in a similar fashion, encompasses all activities that allow an understanding of the real world, shaping attitudes or behaviours. Compared to personal development, it puts a slightly stronger emphasis on the intellectual aspect (Cho et al. 2015).

So what is environmental education? This should be understood as a psychological and pedagogical process that increases peoples knowledge and awareness about the environment and associated challenges, develops the necessary skills and exper- tise to address the challenges, and fosters attitudes, motivations, and commitments to make informed decisions and take responsible action (Tbilisi Declaration, 1977). Education is a concept and process of bringing up members of society, along with their education, in a spirit of respect for nature and understanding the need for its protection, as well as empathy, care and sensitivity towards. Environmental education is often used as a synonym for ecological education, since the concept of environment has close connotations with ecology. To be precise, ecological education is teaching about interactions between living organisms and their groups coexisting in a given abiotic environment. (Stawiński 2006). The purpose of ecological education is to help people understand the processes that take place in nature, to develop the ability to acquire information about the environment, and to explain how the environment is managed. On the other hand, environmental education puts a stronger emphasis on the protection of the natural world, which should be understood as taking relevant action, or abstaining from action, in order to preserve or restore balance in an ecosystem disturbed as a result of damage caused by human activity (Stawiński 2006). This proposed distinction between the two terms means that before starting environmental education people should have a certain level of ecological education.

There are three aspects of environmental education: cognitive, associated with the recognition of man-made damage to nature; behavioural, encompassing attitudes and behaviours, motivating people to actively disapprove of environmentally harmful activities; and volitional-emotional, regarding the stimulation and shaping of sensitivity, respect for the natural environment, and also affecting the positive desires and feelings that people, as moral beings, should have towards nature. This last aspect indicates that environmental education also entails: aesthetic education, manifested by the perception of the beauty of unspoilt nature, ethical education, giving moral status to non-human beings, and psychological education, (Nasibulina 2015).

Today, environmental education requires a redefinition of the still largely valid scientific outlook stemming from the materialistic concepts and ignoring the spiritual aspect which remains in close connection with nature. Environmental education should make people open to the environment, stimulate their creativity and spontaneous cognitive activity, and encourage interaction with other members of society in order to achieve the common good. Environmental education should, therefore, help in broadening the horizons of human knowledge, its understanding, experiencing, imagining and use for the protection of nature and, consequently, for the good of humankind (Parra Moreno et al. 2011).

The exploration of complex relationships between the state of nature and the quality of human life proves not only the human attitude towards nature, but also the state of relations between people 
and their mutual respect for each other. The principal traits driving the actions of a person with a high level of environmental intelligence should be creativity and responsibility. Creativity fulfils its role when it becomes useful in changing present reality, forming new values and refreshing existing ones, and also in stimulating positive emotions and desires. This can be facilitated by knowledge which would not stimulate the further exploitation and destruction of nature, but instead inspire a harmonious and creative coexistence with it (Clayton 2012). The process of environmental education, apart from sharing knowledge and views, strongly requires people to perceive the fragility of nature, and to more deeply experience and comprehend the damage caused by humans to their natural environment, especially if the direct consequences of this process are still not perceived. Experience of all these sensations, however unpleasant to people of the right character, makes people more human, strengthens noble traits, and contributes to a more comprehensive development of a human being, both in the physical, intellectual, sensory and emotional dimensions. The need to evoke positive human feelings towards nature and make people emphatic to the poor state of it is a serious challenge to organizers of all educational initiatives stemming from various historical and cultural backgrounds (Clayton 2012).

\section{Materials and methods}

The level of education in members of the public and the level of their environmental intelligence can only be determined on a scientific basis. For that purpose, a sociological study was carried out between 13 April and 16 October 2015 . The research project was entitled "Awareness of ecological values among students of humanities and natural sciences in selected European countries". The executed project provided data on the knowledge of nature protection among students, threats to nature and their importance, declared views on the state of natural environment, level of environmental culture in respondents, including accepted standards and values and their position among other social values appreciated by students, declared attitudes towards the natural environment, and, where possible, the sensitivity and emotionality of respondents towards environmental problems, as well as the personality traits of respondents who are concerned about the good state of nature.

The survey was carried out in a group of 520 students from 4 universities: the University of Rzeszów (Poland), the University of Prešov (Slovakia), the Rivne State University of Humanities (Ukraine), and the University of Ostrava (Czech Republic). Universities were selected using the snowball sampling method. At each of these universities 130 students in total were surveyed, and of these half were students of humanities or social sciences, while the other half were students of the natural sciences. The respondents were first degree students (first-year students were excluded) or second degree students. All the respondents studied in a full-time programme. The survey was carried out among students of humanities and social sciences (social work, cultural studies, political science, andragogy, philology and history), and natural sciences (food technology and human nutrition, biology, ecology, environmental conservation, agriculture, geography and cartography). Women accounted for $74.6 \%$ and men for $25.4 \%$ of all respondents; $56.0 \%$ of respondents were aged 20 22 years, 32.7\% - 23-25 years, 7.3\% - 17-19 years, and $4.0 \%$ were older than 25 years. With respect to the declared place of permanent residence, $55.1 \%$ of respondents lived in a rural area, $17.9 \%$ in a town with a population up to $49,999,13.5 \%$ - in a city with a population up to $99,999,8.7 \%$ - in a city with a population over 200,000 , and $4.8 \%$ - in a city with a population up to 199,999 . With respect to the declared religious orientation $52.2 \%$ of students were Roman Catholics, 22.2\% were Orthodox, 17.8\% were non-believers, 5.0\% declared other beliefs, and $2.7 \%$ were Protestants.

The most important research problem focusing mainly on investigating the level of environmental education among students from Poland, Czech Republic, Slovakia and Ukraine. In analysis was taken two criteria into account, so it is necessary to examine the state of ecological education presented by students from different countries and faculty of studies.

The research problems correspond to the following research hypotheses: the level of environmental education among students from selected countries of Central Eastern Europe, is relatively low. The higher state environmental awareness was found in Czech and Slovaks students than in Polish and Ukrainian respondents. Finally it can assume that students of natural sciences are significantly better educated than students of humanities because they learn much more material on ecology and environmental protection during their education.

Other specific research problems were formulated in the following questions: What level of knowledge present students? What emotions do respondents experience when it comes to the problems of nature protection? Do the problems related to nature protection stimulate social optimism or pessimism in respondents? What motivates students to care about nature? What values accept students? Which elements of nature deserve, in respondents' opinion, a moral status? These research problems correspond to the following preliminary and general research hypotheses: Students present not satisfied level knowledge about environment. They are aware that the whole ecosystem consists of interconnected and interacting elements. Problems of the natural environment generally stimulate negative emotions in respondents such as anxiety, fear, uncertainty or distress, because in their opinion the state of nature continues to deteriorate. Environmental protection stimulates rather negative feelings in individuals, 
which in the overall balance is reflected in general social pessimism among the respondents. The strongest motivation for students to care for the environment are the short-term benefits that humans can enjoy, and which are reflected, for example, in the potential improvement of the quality of their life. The students prefer particular interests than good of nature. Respondents are concerned that the moral status, which undoubtedly man deserves, should also be ascribed to animals, because animals are particularly sensitive to pain.

A pilot survey was carried on 18 students of the University of Rzeszów in March 2015 to validate the designed research tool. Respondents who participated in the pilot survey were second-year second degree students of philosophy (full-time programme). After the pilot survey minor changes were made, mainly in the structure of some questions. The pilot survey also revealed some difficulties with students' understanding of the term 'moral status', and for this reason it was explained to respondents each time during the study.

\section{Researches results}

An auditory survey was used in order to resolve the formulated research problems and verify the proposed hypotheses. The research tool was a questionnaire containing 18 close-ended and semi-openended questions/statements. Obtained data were used for relevant calculations in the IBM SPSS Statistics software, and the level of statistical significance was adopted at $p=0.05$. Selected questions and the answers to them, with the consideration of variables (country and faculty of studies), are presented below in the text.

Table 1. Understanding of the term environment by respondents (scores in \%)

\begin{tabular}{|c|c|c|c|c|}
\hline \multicolumn{2}{|c|}{ What comes to your mind when you hear environment? } \\
\hline & Poland & Slovakia & Czech Republic & Ukraine \\
\hline green areas and beauty of landscape & 68.6 & 41.4 & 47.7 & 49.2 \\
\hline wild animal species & 2.5 & 1.6 & 0.8 & 1.7 \\
\hline protection of nature & 11.6 & 19.5 & 6.9 & 6.7 \\
\hline climate change & 0 & 0.8 & 3.1 & 2.5 \\
\hline natural disasters & 0 & 0 & 0.8 & 0 \\
\hline environmental disasters caused by human activity & 1.7 & 3.9 & 3.1 & 2.5 \\
\hline depletion of natural resources & 0.8 & 0 & 0 & 0 \\
\hline loss of biodiversity & 0 & 1.6 & 0.8 & 0 \\
\hline preservation of intact environment & 4.1 & 11.7 & 9.2 & 13.3 \\
\hline for future generations & 1.7 & 2.3 & 3.8 & 0 \\
\hline urban pollution & 6.6 & 12.5 & 18.5 & 20.0 \\
\hline all that surrounds us & 2.5 & 3.1 & 0.8 & 0 \\
\hline a place for people to live & 0 & 0 & 0.8 & 1.7 \\
\hline other & 0 & 1.6 & 3.8 & 2.5 \\
\hline
\end{tabular}

Source: authors' own study ${ }^{1}$.

The distribution of answers to the question about associations with the word environment was interesting. Data presented in Table 1 show that the highest percentage of students, regardless of country, indicated 'green areas and beauty of landscape', which can certainly be linked to a specific place or space, and is therefore abstract to some extent. This cannot be said about the statement 'quality of life in the place of my residence', which was pointed out by a fairly large number of students from the Ukraine and Czech Republic. The choice of this answer by the respondents indicated their clearly local orientation; in other words, to some extent it proves that these respondents were more focused on the conditions of their daily existence compared to other groups. Interestingly, 'preservation of intact environment for future generations' was an option indicated by a relatively low percentage of students. Thus, it can be argued that the respondents only slightly showed a holistic and future-oriented way of thinking about the natural world. In some extent, this confirmed the hypothesis that for respondents the environment was seen as the rather limited space of their everyday life. This observation applies more to students from the Czech Republic and Ukraine, who also less often opted for the 'protection of nature', as compared to students from Slovakia and Poland. 
Table 2. Understanding of the term environment by respondents (scores in \%)

\begin{tabular}{|c|c|c|}
\hline \multicolumn{2}{|c|}{ What comes to your mind when you hear environment? } \\
\hline & faculty of natural sciences & $\begin{array}{c}\text { faculty of humanities } \\
\text { and social sciences }\end{array}$ \\
\hline green areas and beauty of landscape & 47.7 & 55.1 \\
\hline wild animal species & 2.5 & 0.8 \\
\hline protection of nature & 13.6 & 9.0 \\
\hline climate change & 1.6 & 0 \\
\hline natural disasters & 0.4 & 2.6 \\
\hline environmental disasters caused by human activity & 2.9 & 0.4 \\
\hline depletion of natural resources & 0 & 0.4 \\
\hline loss of biodiversity & 0.8 & 6.3 \\
\hline preservation of intact environment & 13.2 & 2.3 \\
\hline for future generations & 1.6 & 17.2 \\
\hline urban pollution & 11.5 & 1.2 \\
\hline quality of life in the place of my residence & 2.1 & 1.2 \\
\hline all that surrounds us & 0 & 2.0 \\
\hline
\end{tabular}

Source: authors' own study.

Data presented in Table 2 do not clearly indicate a relationship between the variable: faculty of studies and respondents' associations with the natural environment. The answer having no specific reference to space was most frequently given by students of the humanities, and slightly less often by students of natural sciences. Besides, compared to students of humanities, twice as many students of the natural sciences indicated 'preservation of intact environ- ment for future generations', and more 'naturalists' also identified environment with the protection of nature. In contrast, students of humanities more frequently indicated 'the quality of life in the place of my residence'. This shows that 'naturalists', to a slightly larger extent, had a tendency to think in holistic terms than the 'humanists', who in turn presented a slightly higher degree of reductionist thinking.

Table 3. Concerns of respondents about the state of nature (scores in \%)

\begin{tabular}{|c|c|c|c|c|}
\hline \multicolumn{5}{|c|}{ I am concerned about climate change } \\
\hline & Poland & Slovakia & Czech Republic & Ukraine \\
\hline strongly agree & 24.0 & 36.8 & 29.1 & 19.0 \\
\hline agree & 55.0 & 44.8 & 45.7 & 61.1 \\
\hline disagree & 14.0 & 15.2 & 18.9 & 11.1 \\
\hline strongly disagree & 3.9 & 1.6 & 3.9 & 4.0 \\
\hline undecided & 3.1 & 1.6 & 2.4 & 4.8 \\
\hline \multicolumn{5}{|c|}{ I am concerned about consumer habits } \\
\hline strongly agree & 18.5 & 17.8 & 23.0 & 1.6 \\
\hline agree & 35.4 & 31.0 & 36.5 & 35.0 \\
\hline disagree & 38.5 & 34.9 & 28.6 & 39.8 \\
\hline strongly disagree & 5.4 & 7.8 & 6.3 & 5.7 \\
\hline undecided & 2.3 & 8.5 & 5.6 & 17.9 \\
\hline \multicolumn{5}{|c|}{ I am concerned about the future of humankind } \\
\hline strongly agree & 26.6 & 34.6 & 24.4 & 4.9 \\
\hline agree & 38.3 & 23.6 & 25.2 & 47.5 \\
\hline disagree & 21.9 & 21.3 & 32.3 & 15.6 \\
\hline strongly disagree & 5.5 & 7.9 & 14.2 & 0 \\
\hline undecided & 7.8 & 12.6 & 3.9 & 32.0 \\
\hline
\end{tabular}

Source: authors' own study. 
The distribution of answers presented in Table 3 does not reveal so much the level of holistic thinking by respondents, but more the feelings and emotions they experience when facing problems related to the protection of the natural environment. Each of the listed issues stimulated negative emotions such as anxiety, fear and distress in a significant proportion of respondents. Therefore, it can be concluded that the issues relating to the protection and threats to the natural environment caused psychological discomfort in respondents, which in overall balance was manifested as social pessimism. One exception to this case involved students from the Ukraine, and for most of them one issue, i.e. consumer habits, caused no major concerns, which can probably be explained by the fact that the Ukrainian society is relatively poor and has no strongly developed consumerist lifestyle. More detailed information was obtained from the statistical analysis for this question, and the chi-square test yielded $\chi^{2}(12)=45.241 ; p<0.05$. This re- sult positively verified the hypothesis according to which a variable: respondents' concerns about consumer habits depended on the country of study. The value of the C Pearson contingency coefficient was 0.286 , and indicated a moderate power of association between these two variables. Interestingly, about 30\% of Ukrainian students were undecided when asked to specify their concerns about the future of humankind. The chi-square test yielded $\chi^{2}(12)=108.083 ; p<0.05$. This value was statistically significant, and supported the hypothesis according to which a variable, the concerns expressed by respondents about the future of humankind depended on the country of study. The value of the $C$ Pearson contingency coefficient was 0.420 , and indicated the strong power of association between these two variables. Generally, the analysis demonstrated that the negative emotions as well as the social pessimism expressed by students in response to questions about the state of nature depended, in most cases, on the country of study.

Table 4. Concerns of respondents about the state of nature (scores in \%)

\begin{tabular}{|c|c|c|}
\hline \multicolumn{2}{|c|}{ I am concerned about climate change } \\
\hline & faculty of natural sciences & $\begin{array}{c}\text { faculty of humanities } \\
\text { and social sciences }\end{array}$ \\
\hline strongly agree & 27.7 & 26.7 \\
\hline agree & 47.0 & 56.2 \\
\hline disagree & 17.7 & 12.0 \\
\hline strongly disagree & 3.6 & 3.1 \\
\hline undecided & 4.0 & 1.9 \\
\hline \multicolumn{2}{|c|}{ I am concerned about consumer habits } \\
\hline strongly agree & 15.5 & 33.9 \\
\hline agree & 35.1 & 35.8 \\
\hline disagree & 35.1 & 7.8 \\
\hline strongly disagree & 4.8 & 7.4 \\
\hline undecided & 9.6 & 22.7 \\
\hline \multicolumn{2}{|c|}{ I am concerned about the future of humankind } \\
\hline strongly agree & 22.9 & 31.4 \\
\hline agree & 35.7 & 24.3 \\
\hline disagree & 21.3 & 7.1 \\
\hline strongly disagree & 6.8 & 14.5 \\
\hline undecided & 13.3 & \\
\hline
\end{tabular}

Source: authors' own study.

Data presented in Table 4 indicate that climate change aroused concerns in a slightly greater percentage of respondents studying humanities than the natural sciences, while more students of natural sciences were concerned about consumer habits and the future of humankind. More detailed analysis and the chi-square test yielded $\chi^{2}(4)=6.814 ; p=0.146$. Based on this result, the hypothesis stating that the variable: the concerns about climate change expressed by respondents depended on the faculty of studies was rejected. As with concerns about consumer habits, the chi-square test yielded $\chi^{2}(4)=2.605 ; p=0.626$. This val- ue was not statistically significant, and therefore the hypothesis that the variable: students' concerns about consumer habits depended on the faculty of studies was rejected. For the concerns about the future of humankind the chi-square test yielded $\chi^{2}(4)=1.378$; $\mathrm{p}=0.848$. This value was also statistically insignificant, and therefore the hypothesis that the variable: students' concerns about the future of humankind depended on the faculty of studies was rejected. Generally speaking, that there was no correlation between the faculty of studies and negative emotions stimulated in respondents by the problems of nature protection. 
Table 5. Reasons for which respondents declared the need for the protection of nature (scores in \%)

\begin{tabular}{|c|c|c|c|c|}
\hline \multicolumn{7}{|c|}{ Natural environment has to be protected: } \\
\hline & Poland & Slovakia & Czech Republic & Ukraine \\
\hline to improve the quality of human life & 18.6 & 16.5 & 13.2 & 19.8 \\
\hline to reduce the risk of lifestyle diseases & 13.8 & 13.1 & 6.0 & 14.3 \\
\hline to reduce the number of environmental disasters & 8.2 & 12.0 & 11.2 & 13.8 \\
\hline to ensure animal welfare & 11.2 & 8.6 & 9.8 & 2.8 \\
\hline for the beauty of nature & 10.6 & 7.0 & 6.0 & 3.0 \\
\hline for the inherent value of nature & 3.5 & 6.8 & 13.1 & 4.9 \\
\hline to leave nature in the best possible state \\
for future generations
\end{tabular}

Source: authors' own study.

The distribution of answers presented in Table 5 suggests that a considerable percentage of respondents tended to treat nature in an instrumental way. The main reasons for which they declared environmental concerns were short-term benefits that help improve living conditions and the quality of the human life. Exceptionally, the need to protect nature for its inherent value alone was indicated most frequently by students from the Czech Republic. Thus, some of the Czech respondents noted the specific value of the natural world, not only seeing it as a resource necessary for human life. In these students, this type of approach probably coexisted with other traits, which at the same time are elements defining naturalistic personality, for example, modesty, emotionality, empathy, agreeableness and kindness, but not necessarily sensitivity to the beauty of nature. As with the last listed trait, the aesthetic value of nature was a reason indicated by a relatively low percentage of respondents, which shows that the beauty of nature is not widely perceived and appreciated by students. It was found that generally the values of nature, either aesthetic, or symbolic and cognitive, were relatively rarely indicated by respondents. This probably means that a significant proportion of students did not show most of the traits characteristics of the naturalistic personality. It can also be concluded that the level of environmental intelligence among the respondents needed to understand feelings towards the natural world is rather unsatisfactory. This is reflected, for example, by the fairly low percentage of respondents indicating animal welfare. The lowest score with respect to this reason was found among students from the Ukraine.

Table 6. Reasons for which respondents declared the need for the protection of nature (scores in \%)

\begin{tabular}{|c|c|c|}
\hline \multicolumn{2}{|c|}{ Natural environment has to be protected: } \\
\hline & faculty of natural sciences & $\begin{array}{c}\text { faculty of humanities } \\
\text { and social sciences }\end{array}$ \\
\hline to improve the quality of human life & 17.1 & 20.0 \\
\hline to reduce the risk of lifestyle diseases & 7.8 & 13.6 \\
\hline to reduce the number of environmental disasters & 12.5 & 9.0 \\
\hline to ensure animal welfare & 4.4 & 5.0 \\
\hline for the beauty of nature & 3.1 & 4.3 \\
\hline for the inherent value of nature & 5.7 & 17.2 \\
\hline to leave nature in the best possible state & 25.7 & 22.2 \\
\hline for future generations & 23.8 & \\
\hline to prevent the extinction of life on Earth & & \\
\hline
\end{tabular}

Source: authors' own study.

Data presented in Table 6, as in the case of the country of study, indicate that personal interests, i.e. expected benefits from the protection of nature that humankind can gain, both for individuals and as a species, were the main reason compelling students of humanities and social sciences to care for nature. In addition, a slightly higher proportion of humanities students showed greater sensitivity to the beauty of nature and animal welfare. This fact may suggest that these respondents have a slightly higher level of environmental awareness. On the other hand, natural sciences students appeared to have 
a wider imagination and a tendency to think in holistic terms, which was reflected in their awareness of the long-term effects of the state of the natural environment that will be left to future generations of people and other forms of life. There were some differences between the percentage of students of natural sciences and humanities with respect to the instrumental treatment of nature today and its state in the future, but considering the indicators of environmental awareness (ability to perceive and understand the beauty of nature, its inherent value or animal welfare) the differences were slight. Therefore, it can be concluded that there was no correlation between the faculty of studies and the development of environmental awareness in respondents.

Table 7. Views of students on the moral status of selected elements of nature (scores in \%)

\begin{tabular}{|c|c|c|c|c|}
\hline \multicolumn{5}{|c|}{ Animals deserve to have a moral status } \\
\hline & Poland & Slovakia & Czech Republic & Ukraine \\
\hline strongly agree & 45.0 & 46.4 & 53.2 & 26.0 \\
\hline agree & 38.0 & 35.2 & 31.0 & 52.8 \\
\hline disagree & 10.9 & 12.0 & 10.3 & 15.0 \\
\hline strongly disagree & 4.7 & 3.2 & 3.2 & 3.1 \\
\hline undecided & 1.6 & 3.2 & 2.4 & 3.1 \\
\hline \multicolumn{5}{|c|}{ Plants deserve to have a moral status } \\
\hline strongly agree & 20.2 & 36.5 & 38.9 & 22.1 \\
\hline agree & 46.5 & 37.3 & 37.3 & 50.0 \\
\hline disagree & 22.5 & 15.1 & 15.9 & 21.3 \\
\hline strongly disagree & 7.0 & 5.6 & 4.0 & 2.5 \\
\hline undecided & 3.9 & 5.6 & 4.0 & 4.1 \\
\hline \multicolumn{5}{|c|}{ Microorganisms deserve to have a moral status } \\
\hline strongly agree & 13.3 & 19.5 & 20.6 & 3.4 \\
\hline agree & 36.7 & 35.0 & 35.7 & 25.2 \\
\hline disagree & 29.7 & 31.7 & 31.0 & 44.5 \\
\hline strongly disagree & 11.7 & 7.3 & 6.3 & 12.6 \\
\hline undecided & 8.6 & 6.5 & 6.3 & 14.3 \\
\hline \multicolumn{5}{|c|}{ Inanimate nature deserves to have a moral status } \\
\hline strongly agree & 18.1 & 19.4 & 28.0 & 8.3 \\
\hline agree & 38.6 & 40.3 & 35.2 & 30.0 \\
\hline disagree & 29.9 & 25.8 & 24.8 & 37.5 \\
\hline strongly disagree & 7.1 & 8.1 & 7.2 & 10.0 \\
\hline undecided & 6.3 & 6.5 & 4.8 & 14.2 \\
\hline
\end{tabular}

Source: authors' own study.

The distribution of answers presented in Table 7 indicates that the majority of respondents were ready to ascribe a moral status to animals, plants or even microorganisms and inanimate nature, with the exception of Ukrainian students, most of whom would not ascribe such a status to microorganisms and inanimate nature. It should be clarified here that moral status is understood in this case as the value or importance of a specific element in autotelic terms, not instrumental, and which because of this deserves respect from humans (DeGrazia 2002). All beings live according to their nature, possess individual welfare and must be treated as ends-in-themselves. This individual welfare is a sufficient reason to ascribe moral status to all beings; another reason can be the inherent value they possess. The inherent value of elements of nature means that their welfare deserves to be the object of reflection and commitment of all members of society, and that the pursuit to achieve this welfare is inherently justified (Tyburski 2013). The analysis of data in Table 7 shows that students from the Czech Republic gave the highest number of positive answers with respect to each of the listed elements of nature. When it comes to ascribing moral status to plants, statistical analysis of scores yielded $\chi^{2}(12)=22.048 ; p=0.037$. This value was statistically significant, and supported the hypothesis according to which a variable: the tendency to ascribe moral status to plants by students correlate with the country of study. The value of the C Pearson contingency 
coefficient was 0.205 , and indicated a moderate power of association between these two variables. With respect to the autotelic value of microorganisms the chi-square test yielded $\chi^{2}(12)=33.568 ; p=0.001$. This value was statistically significant, and therefore positively verified the hypothesis stating the variable: the willingness to ascribe a moral status to microorganisms depended on the country of study. The value of the C Pearson contingency coefficient was 0.252 , indicating a moderate power of association between these two variables. With respect to the autotelic value of inanimate nature, e.g. seas and mountains, the chi-square test yielded $\chi^{2}(12)=28.140 ; p=0.005$.
This value was statistically significant, and supported the hypothesis according to which a variable: the tendency to ascribe moral status to inanimate nature by students depended on the country of study. The value of the $C$ Pearson contingency coefficient was 0.232 , indicating a moderate power of association between these two variables. Of note, respondents who declared that they would ascribe autotelic value to different elements of nature in part also opted for the equal treatment of all beings. One exception in this regard were Ukrainian students, the majority of whom would not give equal status to microorganisms and inanimate nature.

Table 8. Views of students on the moral status of selected elements of nature (scores in \%)

\begin{tabular}{|c|c|c|}
\hline \multicolumn{3}{|c|}{ Animals deserve to have a moral status } \\
\hline & faculty of natural sciences & $\begin{array}{l}\text { faculty of humanities } \\
\text { and social sciences }\end{array}$ \\
\hline strongly agree & 38.6 & 46.5 \\
\hline agree & 43.4 & 35.2 \\
\hline disagree & 13.5 & 10.5 \\
\hline strongly disagree & 2.8 & 4.3 \\
\hline undecided & 1.6 & 3.5 \\
\hline \multicolumn{3}{|c|}{ Plants deserve to have a moral status } \\
\hline strongly agree & 28.0 & 30.7 \\
\hline agree & 44.7 & 40.9 \\
\hline disagree & 20.7 & 16.7 \\
\hline strongly disagree & 4.1 & 5.4 \\
\hline undecided & 2.4 & 6.2 \\
\hline \multicolumn{3}{|c|}{ Microorganisms deserve to have a moral status } \\
\hline strongly agree & 14.8 & 13.8 \\
\hline agree & 33.3 & 33.2 \\
\hline disagree & 36.6 & 31.6 \\
\hline strongly disagree & 8.6 & 10.3 \\
\hline undecided & 6.6 & 11.1 \\
\hline \multicolumn{3}{|c|}{ Inanimate nature deserves to have a moral status } \\
\hline strongly agree & 15.9 & 21.1 \\
\hline agree & 34.7 & 37.5 \\
\hline disagree & 34.3 & 24.7 \\
\hline strongly disagree & 8.6 & 7.6 \\
\hline undecided & 6.5 & 9.2 \\
\hline
\end{tabular}

Source: authors' own study.

The distribution of answers presented in Table 8 for the first three variables (moral status of animals, plants and microorganisms) shows that there were minor differences between the views expressed by students of natural sciences and humanities. Greater differences were found only with respect to the autotelic value of inanimate nature. Detailed analysis with a focus on the first variable (moral status of animals) yielded $\chi^{2}(4)=7.621 ; p=0.106$. The value was not statistically significant, and thus the hypothesis stating the variable: the views of students regarding the moral status of animals correlate with the faculty of study was rejected. With respect to the second variable, i.e. autotelic value of plants, the chi-square yielded $\chi^{2}(4)=6.447 ; p=0.168$. This value also negatively verified the hypothesis that the variable: the views of students regarding the moral status of plants depend on the faculty of study. As with the autotelic 
value of microorganisms, the chi-square test yielded $\chi^{2}(4)=4.153 ; p=0.386$, and the hypothesis stating the variable: the views of students regarding the moral status of microorganisms depend on the faculty of study was also rejected. Similar findings were made on the autotelic value of inanimate nature. For this variable, the chi-square test yielded $\chi^{2}(4)=7.183$; $\mathrm{p}=0.127$. Therefore, the hypothesis that the variable: the views of students regarding the moral status of inanimate nature depend on the faculty of study was rejected. It can also be concluded from data in Table 8 that students - regardless of the faculty of studies - were not strongly in favour of species egalitarianism, as for most of them microorganisms had no autotelic value, although other elements of inanimate nature did have it.

\section{Conclusions}

The analysis of results from the carried out study demonstrated that the level of environmental education among students from selected countries of Central Eastern Europe, is relatively low. Even more disturbing observations arise from a deeper analysis of the level of their environmental education. This general conclusion suggests that the process of educating students in environmental protection leaves much to be desired, and the ethical and aesthetic aspect of the man-nature relationship is particularly neglected.

In order to explore the above observations, it is necessary to compare the levels of environmental education with consideration of the two criteria adopted in our research project, i.e. the country of study and faculty of study. More Slovak and Polish respondents were also concerned about processes with negative impact on the natural environment compared to students from the Czech Republic, and particularly those from the Ukraine. This means that they probably felt stronger anxiety, distress, uncertainty and fear with respect to threats existing in the natural world. Additionally, issues of environmental protection and degradation of nature stimulated in respondents a fairly widespread social pessimism.

Some Czech respondents indicated the inherent value of nature as the main reason encouraging its protection, and thus were inclined to ascribe a moral status to selected elements of nature. Most likely, the fact that more than half of the Czech respondents declared themselves non-believers made them more inclined to choose the statement about the man-nature relationship founded on moral and non-religious principles, and also the statement on the equal treatment of individual elements of the natural environment. In contrast, in the Ukraine the lowest percentage of students demonstrated traits of environmental education, and also the fewest respondents opting for the equal treatment of all elements of nature. In addition, Ukrainian respondents most frequently indicated benefits from the use of nature as a reason for which they care for nature. Of note, this reason was only slightly less often indicated by respondents from other countries. Nevertheless, survey results suggest that Ukrainian students were also less awareness to the state of nature, and thus they had a lower level of environmental education. To some extent this view is justified by the observation that a certain number of respondents pointed to the inherent value of nature as the main reason for its protection.

However, this does not finally explain the level of awareness which respondents had at the moment of giving answers to survey questions. It is possible that thinking and awareness among students were stimulated immediately in response to the read survey questions. Also, it cannot be ruled out that respondents deliberately did not give honest answers as they wanted, for example, to present themselves in a certain way.

As with another criterion: faculty of study; students of natural science expressed concerns, anxiety and fear about threats to the environment and the consequences of this state of affairs. In addition, a significant percentage of respondents - regardless of the faculty of studies - presented social pessimism about problems related to the environment. Likewise, a similar percentage of people - with a slight shift towards the natural science students - were ready to ascribe a moral status to individual elements of nature, categorising them as entities with an autotelic value. A slightly greater percentage of humanities students, however, were ready to ascribe a moral status to inanimate nature. This is reflected in the fact that only a slightly higher percentage of students of natural sciences than humanities students indicated the inherent value of nature as the main reason for nature protection, while more humanities students indicated the beauty of nature and animal welfare.

Obviously, natural sciences should play a special role in the process of environmental education, but apparently - as our study revealed - university education systems in Central European countries put the strongest emphasis on understanding nature in a theoretical manner: reductionist, specialized, mechanized, including the setting of laboratory experiments. Although spectacular successes have been achieved in these areas of the natural sciences, the greatest progress will be made when they are used for teaching young people how to interact with nature and how to effectively protect it. However, the physical contact of students with nature does not mean that they will develop a higher level of environmental education. Experiencing nature alone is not the same as understanding it and being sensitive to its state; this would require tuning into harmonious life with nature and understanding the human impact on the natural environment, facilitated by knowledge, assimilated ecological values. The people should have at least minimum information about nature to be able to consciously interact with it and care for it properly. As experience shows, people are more likely to respect what they understand. 
The overall analysis allows the conclusion that the highest level of environmental education was found in Czech students, followed by Slovaks, Poles and Ukrainians. In addition, only a slightly greater mental capability of comprehending environmental values was presented by students of natural sciences compared to humanities students. This observation may be somewhat disturbing. Although students of natural sciences learn much more material on ecology and environmental protection during their education, findings from the carried out survey did not indicate that they are significantly better educated in this area. On the other hand, this can put students of humanities in a better light, as they, with respect to some aspects, stood out by presenting a more moral point of view on the problems of ecology and environmental protection.

Conclusions from the study finally indicate that students in general do not feel connected to nature, and detach themselves from it on the cognitive, but also emotional levels, which in a sense is understandable, as this would also mean a detachment from the source of distress arising from the existing environmental problems. However, by doing so young people avoid accepting responsibility for the state of nature, which, to a large extent, reflects the state of contemporary humankind.

\section{Acknowledgements}

This paper has been financed from a special purpose grant of MSHE, project no. IS-01/2015/508.

\section{References:}

1. Cho Y.H., Choi H., Shin J., Yu H.C., Kim Y.K., Kim J.Y. (2015), Review of research on online learning environments in higher education. Procedia - Social and Behavioral Sciences, 191, pp. 2012-2017.

2. Clayton S. (ed.), (2012), The Oxford Handbook of environment al and conservation psychology. Oxford University Press, New York.

3. DeGrazia D. (2002), Animal rights: A very short introduction. Oxford.

4. Dobrzańska B., Dobrzański G., Kiełczewski D. (2008), Ochrona środowiska przyrodniczego. Wydawnictwo Naukowe PWN, Warszawa.

5. Nasibulina A. (2015), Education for sustainable development and environmental ethics. Procedia - Social and Behavioral Sciences, 214, pp. 1077-1082.

6. Parra Moreno C.H., Moreno Acero I.D., Puendes Rodrigez N.H. (2011), Education for environment care: contribution through human ecology. Procedia - Social and Behavioral Sciences, 15, pp. 3912-3915.

7. Stawiński W. (ed.) (2006), Dydaktyka biologii i ochrony środowiska. Wydawnictwo Naukowe PWN, Warszawa.

8. Tibilisi Declaration (1977), https://www.gdrc.org/uem/ee/tbilisi.html (accessed: 10.12.2016).

9. Tyburski W. (2013), Dyscypliny humanistyczne i ekologia. Wydawnictwo Naukowe Uniwersytetu Mikołaja Kopernika, Toruń.

10. Wolarski W. (ed.) (2002), Britannica. t. 28, Mu-Ni, Kurpisz, Poznań 